\title{
Pembuatan Aplikasi Metadata Generator untuk Koleksi Peninggalan Warisan Budaya
}

\author{
Wimba Agra Wicesa, Sarwosri, dan Nurul Fajrin Ariyani \\ Jurusan Teknik Informatika, Fakultas Teknologi Informasi, Institut Teknologi Sepuluh Nopember
}

(ITS)

Jl. Arief Rahman Hakim, Surabaya 60111 Indonesia

J. Ar:

\begin{abstract}
Abstrak-Warisan budaya merupakan suatu aset penting yang digunakan sebagai sumber informasi dalam mempelajari ilmu sejarah. Mengelola data warisan budaya menjadi suatu hal yang harus diperhatikan guna menjaga keutuhan data warisan budaya di masa depan. Menciptakan sebuah metadata warisan budaya merupakan salah satu langkah yang dapat diambil untuk menjaga nilai dari sebuah artefak. Dengan menggunakan konsep metadata, informasi dari setiap objek warisan budaya tersebut menjadi mudah untuk dibaca, dikelola, maupun dicari kembali meskipun telah tersimpan lama. Selain itu dengan menggunakan konsep metadata, informasi tentang warisan budaya dapat digunakan oleh banyak sistem. Metadata warisan budaya merupakan metadata yang cukup besar. Sehingga untuk membangun metada warisan budaya dibutuhkan waktu yang cukup lama. Selain itu kesalahan (human error) juga dapat menghambat proses pembangunan metadata warisan budaya. Proses pembangkitan metadata warisan budaya melalui Aplikasi Metadata Generator menjadi lebih cepat dan mudah karena dilakukan secara otomatis oleh sistem. Aplikasi ini juga dapat menekan human error sehingga proses pembangkitan menjadi lebih efisien.
\end{abstract}

Kata Kunci-CIDOC-CRM, Metadata, Warisan Budaya.

\section{PENDAHULUAN}

$\mathrm{W}$ ARISAN budaya merupakan suatu aset penting yang digunakan sebagai sumber informasi dalam mempelajari ilmu sejarah. Mengelola data warisan budaya menjadi suatu hal yang harus diperhatikan guna menjaga keutuhan data warisan budaya di masa depan. Warisan budaya dapat disimpan dalam bentuk objek 3D maupun objek 2D berupa dokumentasi foto atau gambar. Namun objek tersebut akan menjadi kurang bernilai jika tidak disertai dengan informasi yang mendukung, seperti nama, lokasi penemuan, perkiraan umur, siapa pembuatnya dan bahan apa yang digunakan. Informasi dari setiap objek warisan budaya tersebut harus terlampir, disusun sedemikian rupa sehingga mudah untuk dibaca, dikelola, maupun dicari kembali meskipun telah tersimpan lama. Struktur data seperti inilah yang disebut dengan metadata.

Metadata adalah data tentang data atau informasi tentang informasi. Metadata adalah bentuk database modern yang saat ini sudah banyak digunakan dalam bidang teknologi informasi. Dengan menggunakan sistem metadata informasi yang terkandung dapat digunakan oleh banyak sistem. Ada berbagai macam framework yang dapat digunakan untuk membangun metadata, salah satunya adalah RDF (Resource Description Framework). RDF adalah sebuah framework yang berasal dari teknologi Extensible Markup Language (XML), dan sedang dikembangkan di bawah naungan World Wide Web Consortium (W3C). RDF disusun menggunakan kode XML. Bahasa XML yang digunakan oleh RDF disebut RDF/XML [1].

Sebuah struktur metadata dengan RDF mengacu pada sebuah file RDFS (Resource Description Framework Schema). File ini berperan sebagai acuan (rule) dalam pembangunan metadata RDF. CIDOC (ICOM's International Committee for Documentation) adalah salah satu RDFS yang tersedia. CIDOC dibangun pada tahun 2006 untuk menciptakan sebuah acuan tentang entitas dan property yang digunakan dalam metadata warisan budaya [1].

Saat ini untuk dapat menerapkan struktur metadata yang kompleks pada data warisan budaya merupakan hal yang rumit bagi sebagian orang. Karena dibutuhkan keahlian khusus yang harus dimiliki. Selain itu untuk membangun sebuah metadata yang besar, seperti data warisan budaya, dibutuhkan waktu yang lama apabila hal tersebut dilakukan secara manual. Tidak bisa dipungkiri kesalahan (human error) dalam proses pembuatan kode juga menjadi kendala yang sering terjadi dalam pembangunan metadata.

Untuk mengatasi masalah tersebut maka dalam penelitian ini akan dibangun sebuah aplikasi berbasis dekstop yang dapat digunakan sebagai generator dalam membangun metadata untuk warisan budaya. Aplikasi ini dapat mengubah data dalam bentuk tabel (Excel) menjadi metadata dalam bentuk RDF/XML dengan mengacu pada RDF Schema CIDOC. Hal ini tentunya akan mengurangi kendala dalam pembangunan metadata warisan budaya, seperti human error. Selain itu dengan menggunakan aplikasi ini proses penyusunan kode metadata akan menjadi lebih cepat karena dilakukan secara otomatis oleh sistem.

\section{TINJAUAN PUSTAKA}

\section{A. Warisan Budaya}

Warisan budaya adalah bentuk ekspresi dari pola hidup kelompok masyarakat yang diwariskan secara turun temurun dari genenrasi ke generasi berikutnya, seperti cara berpakaian, praktek ritual, tempat, objek, aliran seni dan norma yang berlaku. Warisan budaya dapat diekspresikan dalam bentuk sesuatu yang berwujud maupun tidak berwujud [2].

\section{B. Metadata}

Metadata adalah informasi terstruktur yang 


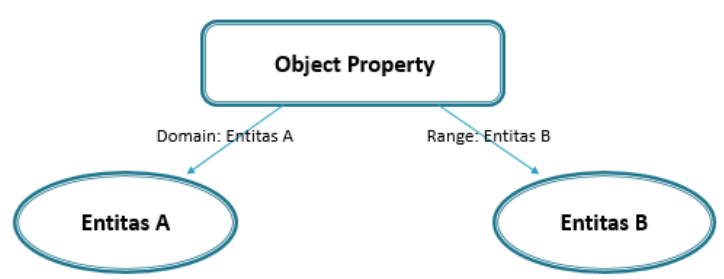

Gambar 1. Hubungan Entitas dan object property pada konsep ontologi

mendeskripsikan, menjelaskan, menemukan, atau setidaknya menjadikan suatu informasi mudah untuk ditemukan kembali, digunakan, atau dikelola. Metadata sering disebut sebagai data tentang data atau informasi tentang informasi [3].

Metadata adalah informasi tambahan yang menyertai dan mendeskripsikan tentang sebuah data tertentu. Misalnya, sebuah gambar memiliki metadata yang menginformasikan seberapa besar ukuran file gambar, kedalaman warnanya, resolusinya, kapan dibuat, dan sebagainya. Contoh lain, metadata sebuah dokumen teks berisi informasi tentang seberapa panjang dokumen tersebut, siapa yang membuat, kapan ditulis, dan ringkasan isinya. Adapun metadata pada halaman website adalah bagian yang dituliskan pada tag meta di bagian header halaman web, misalnya deskripsi singkat tentang website dan keyword-nya [4].

\section{Ontologi}

Ontologi merupakan suatu teori tentang makna dari suatu objek, serta hubungan objek tersebut yang mungkin terjadi pada suatu domain pengetahuan. Ontologi juga merupakan sebuah uraian formal yang menjelaskan tentang sebuah konsep dalam sebuah domain tertentu (Classes, terkadang disebut konsep), properties dari masing-masing konsep menjelaskan bermacam-macam fitur dan atribut dari sebuah konsep (Slots, terkadang disebut rules atau properties). Sebuah ontologi bersama dengan seperangkat instances (menyatakan objek pada suatu domain) dari class membentuk sebuah knowledge base.

Ontologi terdiri dari beberapa komponen penyusun yang digunakan untuk mendeskripsikan sebuah pengetahuan terhadap objek. Komponen tersebut adalah Classes, Instance, dan Relation. Hubungan entitas dan object property pada konsep ontologi disajikan pada Gambar 1.

\section{Resource Description Framework Schema (RDFS)}

Resource Description Framework Schema (RDFS), atau yang biasa dikenal dengan RDF Schema, adalah bentuk pengembangan dari file RDF. RDF Schema merupakan sebuah file yang menjelaskan mekanisme untuk menyusun sebuah RDF. Di dalam RDF Schema dijelaskan nama dan karakteristik dari setiap kelas (Entitas) dan relasi yang menggambarkan hubungan dari setiap kelas tersebut (Data Property). RDF Schema disusun dengan menggunakan kode RDF [10].

\section{E. CIDOC-CRM}

CIDOC (ICOM's International Committee for Documentation) adalah salah satu RDFS yang tersedia. CIDOC dibangun pada tahun 2006 untuk menciptakan sebuah
Tabel 1.

Atribut dataset yang digunakan

\begin{tabular}{|c|c|c|}
\hline No & Nama Atribut & Penjelasan \\
\hline 1 & No Urut & $\begin{array}{l}\text { Berisi nomor urut penemuan artefak. Pada } \\
\text { penelitian ini No Urut dijadikan sebagai } \\
\text { identitas unik dari masing-masing artefak. }\end{array}$ \\
\hline 2 & Nama Benda & Nama artefak \\
\hline 3 & $\begin{array}{l}\text { Tempat Asal } \\
\text { Des/Kec }\end{array}$ & $\begin{array}{l}\text { Desa atau kecamatan tempat ditemukannya } \\
\text { artefak }\end{array}$ \\
\hline 4 & Tempat Asal Kab & Kabupaten tempat ditemukannya artefak \\
\hline 5 & Tempat Asal Prop & Proponsi tempat ditemukannya artefak \\
\hline 6 & Lokasi Gedung & $\begin{array}{l}\text { Lokasi gedung tempat penyimpanan artefak } \\
\text { saat ini }\end{array}$ \\
\hline 7 & Lokasi Ruang & $\begin{array}{l}\text { Lokasi ruang tempat penyimpanan artefak } \\
\text { saat ini }\end{array}$ \\
\hline 8 & Lokasi Lemari/Laci & $\begin{array}{l}\text { Lokasi lemari/laci tempat penyimpanan } \\
\text { artefak saat ini }\end{array}$ \\
\hline 9 & Lokasi Lain & $\begin{array}{l}\text { Lokasi lain tempat penyimpanan artefak saat } \\
\text { ini }\end{array}$ \\
\hline 10 & Kondisi & Kondisi artefak \\
\hline 11 & Bahan & $\begin{array}{l}\text { Bahan yang digunakan untuk membuat } \\
\text { artefak }\end{array}$ \\
\hline 12 & Ukuran Panjang & Ukuran panjang artefak \\
\hline 13 & Ukuran Lebar & Ukuran lebar artefak \\
\hline 14 & Ukuran Tinggi & Ukuran tinggi artefak \\
\hline 15 & Ukuran Tebal & Ukuran tebal artefak \\
\hline 16 & Ukuran Diameter & Ukuran diameter artefak \\
\hline 17 & Tempat Perolehan & Tempat perolehan artefak \\
\hline 18 & Tempat Pembuatan & Perkiraan tempat pembuatan artefak \\
\hline 19 & Tahun Pembuatan & Perkiraan tahun pembuatan artefak \\
\hline
\end{tabular}

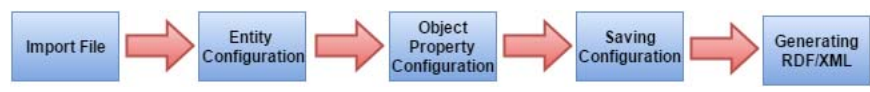

Gambar 2. Alur proses utama pembangkitan metadata warisan budaya

acuan tentang entity dan property yang digunakan dalam penyusunan metadata warisan budaya [5]. CIDOC Conceptual Reference Model (CRM) menyediakan definisi dan struktur yang formal untuk menggambarkan kelas implisit maupun eksplisit dan hubungan yang digunakan dalam dokumentasi data warisan budaya [6].

\section{METODOLOGI}

\section{A. Dataset}

Dataset yang digunakan adalah data artefak Museum Indonesia. Dataset ini berisi 206 informasi artefak yang disajikan dalam bentuk tabel Excel. Setiap data artefak diikuti dengan 19 aribut yang menjelaskan artefak tersebut. Proses penyesuaian dataset diperlukan untuk menjadikan dataset sesuai dengan kebutuhan sistem. Kesembilan belas nama atribut yang digunakan dalam proses pembangkitan metadata disajikan pada Tabel 1.

\section{B. Proses Pembangkitan Metadata}

Secara garis besar proses pembangkitan metadata pada aplikasi ini ditunjukkan pada Gambar 2.

Dari Gambar 2 di atas dapat dilihat bahwa dalam mengenerate metadata dibutuhkan lima proses utama: Import File, Entity Configuration, object property Configuration, Saving 
Configuration, dan Generating RDF/XML. Detail dari setiap proses dijelaskan sebagai berikut.

\section{Import File}

Pada tahap ini sistem melakukan inisialisasi terhadap resources yang dibutuhkan dalam proses pembangkitan metadata. Resources tersebut berupa file RDFS CIDOC dan file Excel yang berisi data artefak Museum Indonesia. Pengguna juga dapat memasukkan file konfigurasi, yang terdiri dari mapping file dan RDFS Configuration, yang telah dibangun sebelumnya.

\section{Entity Configuration}

Pada tahap ini dilakukan pemilihan terhadap entitas CIDOC yang akan digunakan dalam proses pembangkitan metadata. Sistem akan menampilkan semua entitas yang terdapat pada RDFS CIDOC. Selanjutnya pengguna akan memetekan setiap atribut dari dataset dengan entitas CIDOC. Setiap atribut dapat dipetakan dengan entitas yang sama atau berbeda tergantung dari kebutuhan pengguna.

Pada tahap ini juga diatur tingkat threshold yang merupakan batas kedalaman dari entitas. Kedalam entitas yang dimaksud adalah seberapa jauh sistem menelusuri parent dari entitas yang dipilih. Semakin tinggi nilai threshold maka entitas yang terlibat akan semakin banyak.

\section{3. object property Configuration}

Pada tahap ini pengguna harus menentukan object property apa yang akan dilibatkan dalam proses pembangkitan metadata. Sistem akan menampilkan daftar object property yang sesuai dengan entitas terpilih. Selanjutnya pengguna memilih object property sesuai dengan kebutuhan.

\section{Saving Configuration}

Pada tahap ini sistem akan menyimpan konfigurasi yang telah dilakukan oleh pengguna. Konfigurasi tersebut disimpan dalam dua buah file yaitu mapping file dan RDFS Configuration. Mapping file merupakan konfigurasi pemetaan atribut dataset dengan entitas CIDOC, sedangkan RDFS Configuration berisi deskripsi dari entitas dan object property yang telah dipilih oleh pengguna.

\section{Generating RDF/XML}

Tahap terakhir dari deretan proses pembangkitan metadata adalah pembangkitan file RDF/XML dari dataset Excel berdasarkan konfigurasi yang telah dilakukan oleh pengguna. Sebelumnya pengguna harus menentukan lokasi dari file tersebut. Selanjutnya sistem akan menghasilkan file RDF/XML untuk setiap data artefak pada dataset Excel dan meletakkanya pada lokasi yang telah ditentukan.

\section{Pemilihan Entitas dan object property}

Pada tahap sebelumnya sistem telah menyimpan setiap entitas dalam sebuah array Entitas. Selanjutnya pengguna akan menentukan entitas yang cocok untuk setiap atribut pada

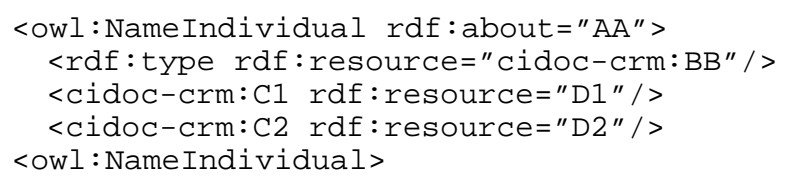

\section{Kode Sumber 1. Format RDF/XML yang dibangun}

dataset Excel Artefak Museum Nasional. Setiap atribut dapat dipetakan ke dalam entitas yang sama atau berbeda satu sama lain tergantung dari kebutuhan pengguna. Hasil pemetaan atribut dengan entitas selanjutnya disimpan dalam file Mapping.txt yang secara otomatis dimunculkan oleh sistem. File tersebut dapat digunakan untuk membangun metadata warisan budaya di waktu selanjutnya.

Setiap entitas yang terdapat pada RDF Schema CIDOC (kecuali E1_CRM_Entity) merupakan bentuk penurunan dari entitas yang lebih besar. Konsep tersebut didefinisikan dalam atribut subClassOf. Pengguna juga dapat menentukan tingkat kedalaman entitas yang dipilihnya. Misalkan pengguna menentukan tingkat kedalaman entitas sebesar dua, maka entitas yang terbaca oleh sistem adalah entitas terpilih dan dua tingkat entitas di atasnya yang ditentukan dari atribut subClassOf.

Setelah sistem menyimpan entitas terpilih selanjutnya sistem akan menampilkan object property yang terkait dengan entitas terpilih. Terkait disini berarti object property mengandung entitas terpilih pada domain, range, atau keduanya.

\section{Pembangunan RDF Schema Configuration}

Kombinasi dari entitas dan object property yang dipilih oleh pengguna merupakan sebuah pengaturan dari proses pembangkitan metadat oleh sistem. Proses ini dapat memakan waktu yang cukup lama karena pengguna harus mengerti mengenai apa yang dipilih. Untuk itu hasil konfigurasi tersebut disimpan dalam sebuah RDF Schema, yang selanjutnya disebut sebagai RDF Schema Configuration, guna menghemat waktu dalam proses pembangunan metadata selanjutnya. RDF Schema Configuration merupakan bentuk penyederhanaan dari RDF Schema CIDOC-CRM. RDF Schema Configuration hanya mendeskripsikan entitas dan object property yang dipilih oleh pengguna. Dengan adanya RDF Schema Configuration dapat memudahkan pengguna dalam proses pembangunan metadata di waktu selanjutnya. Pengguna dapat memasukkan RDF Schema Configuration sebagai acuan untuk membangun metadata tanpa melalu proses konfigurasi.

\section{E. Pembangunan Metadata}

Metadata warisan budaya dibangun dalam bentuk format RDF/XML. Format tersebut menggunakan tag XML untuk mendeskripsikan sebuah objek. Deskripsi objek dalam bentuk RDF ditulis sebagai individual yang dinotasikan di dalam tag “NamedIndividual” seperti disajikan pada Kode Sumber 1.

Bentuk metadata yang dibangun merupakan generalisasi dari entitas terpilih, object property terpilih dan dataset artefak Museum Indonesia. Setiap atribut dari artefak didefinisikan 
Tabel 2.

Atribut dataset yang digunakan

\begin{tabular}{ccl}
\hline \hline No & \multicolumn{2}{c}{ Nama Atribut } \\
\hline 1 & AA & $\begin{array}{l}\text { Bagian ini akan diisi nilai dari sebuah atribut pada } \\
\text { sebuah artefak. }\end{array}$ \\
2 & BB & $\begin{array}{l}\text { Bagian ini akan diisi dengan jenis entitas dari RDF } \\
\text { Schema CIDOC-CRM yang telah dipetakan dengan } \\
\text { atribut terkait. }\end{array}$ \\
3 & C1, C2 & $\begin{array}{l}\text { Bagian ini akan diisi dengan object property terpilih } \\
\text { yang memiliki entitas domain BB } \\
\text { Bagian ini akan diisi dengan nilai atribut yang } \\
\text { dipetakan terhadap entitas yang sesuai dengan range } \\
\text { C1/C2 }\end{array}$ \\
\hline \hline
\end{tabular}

<owl: NamedIndividual

rdf: about="http://wWw. semanticweb.org/agra/on tologies/2016/tugasAkhir\#L._28b_(ruang_emas)"

$>$

$<$ rdf: type rdf: resource="cidoc crm:E53_Place"/>

<cidoc-crm:P44_has_condition

rdf: resource="http://WWW. semanticweb.org/tuga

sAkhir\#Baik"/>

$</$ owl: NamedIndividual>

<owl: NamedIndividual

rdf:about="http://WWW. semanticweb.org/tugasAk

hir\#Baik">

$<$ rdf: type rdf: resource="cidoc -

crm:E3_Condition_State"/>

$</$ owl: NamedIndividual>

Kode Sumber 2. Hasil pembangkitan metadata warisan budaya

sebagai entitas sesuai dengan pemetaan pengguna. Selanjutnya setiap atribut dihubungkan dengan atribut lain sesuai dengan object property terpilih dan data pada dataset Excel Museum Indonesia. Proses ini menghasilkan file $\mathrm{RDF} / \mathrm{XML}$ untuk setiap artefaknya. Apabila dalam dataset terdapat 10 artefak, maka sistem akan menghasilkan 10 file $\mathrm{RDF} / \mathrm{XML}$. Contoh file RDF/XML yang akan dibangun disajikan pada Kode Sumber 2.

Kode tersebut mendeskripsikan nilai atribut pada sebuah artefak. Penjelasan kode tersebut disajikan dalam Tabel 2. Dalam sebuah data artefak pada dataset terdapat beberapa nilai atribut sehingga metadata sebuah artefak dalam file $\mathrm{RDF} / \mathrm{XML}$ akan berisi beberapa potongan kode Kode Sumber 2 tergantung dari jumlah atribut pada artefak.

\section{HASIL PENGUJIAN}

Metadata warisan budaya yang dihasilkan berbentuk file $\mathrm{RDF} / \mathrm{XML}$. Setiap file dibangun membentuk metada artefak berdasarkan dataset dan sesuai dengan pengaturan yang telah dilakukan oleh pengguna. Pengujian sintak dari metadata dilakukan dengan bantuan kakas bantu Protege. Apabila salah satu file RDF/XML tersebut dibuka melalui Protege hasilnya akan sesuai dengan informasi artefak terkait pada dataset Excel. Contoh hasil generate metadata melalui Aplikasi Metadata Genertaor dapat dilihat pada Kode Sumber 2.

Pengujian file konfigurasi yang dihasilkan oleh sistem (Mapping file dan RDFS Configuration) dilakukan menggunakan fitur load configuration. Hasil pengujian menunjukkan bahwa file konfigurasi tersebut dapat digunakan untuk proses pembangkitan metadata dan sesuai dengan konfigurasi yang dilakukan oleh pengguna.

\section{KESIMPULAN}

Proses pembangkitan metadata warisan budaya melalui Aplikasi Metadata Generator dilakukan melalui lima tahapan yaitu Import File, Entity Configuration, object property Configuration, Saving Configuration, dan Generating RDF/XML. Sistem mengelola entitas dan object property dengan bantuan framework Jena. File metadata artefak yang dihasilkan telah teruji sesuai dengan informasi pada dataset dengan bantuan kakas bantu Protege. Melalui Aplikasi Metadata Generator proses pembangkitan metadata warisan budaya menjadi lebih cepat dan mudah.

\section{DAFTAR PUSTAKA}

[1] Asalasah, "Ringkasan Materi RDF - Semantic Web," 29112015. [Online]. Available: http://asalasah.net/ringkasan-materi-rdf-semanticweb/. [Diakses 28 Nopember 2016].

[2] Cultural in Development (CiD), "What is Culturaal Heritage," 2012. [Online]. Available: http://www.culturein development.nl/cultural_heritage/what_is_cultural_heritage. [Diakses 14 Desember 2015].

[3] Wikipedia, "Metadata," Wikipedia, 169 2015. [Online]. Available: https://id.wikipedia.org/wiki/Metadata. [Diakses 30 Nopember 2015].

[4] SmitDev Community, "Metadata," Metadata, 97 2010. [Online]. Available: http://www.smitdev.com/posts/metadata362.php. [Diakses 29 Nopember 2015].

[5] W3C, "RDF Schema," W3C, 252 2014. [Online]. Available: http://www.w3.org/TR/rdf-schema/. [Diakses 2 Desember 2015].

[6] International Council of Museums (ICoM), "What is the CIDOC CRM," 512 2014. [Online]. Available: http://www.cidoc-crm.org/. [Diakses 2 Desember 2015]. 